\title{
Household Indebtedness in Malaysia: A Survey Evidence
}

\author{
Nora Azureen Abdul Rahman, Zunarni Kosim, and Siew Goh Yeok
}

\begin{abstract}
Increasing trends in using debts as a mechanism to fill the gap between income and expenditures among Malaysian households motivates this study. This study provides a survey evidence on the indebtedness of Malaysian household, particularly in the types of loans which Malaysian households frequently involved in, whether the debts become a financial burden to the households and whether Malaysian households have any alternative source of income as a financial backup for their main income. The survey shows that most Malaysian households having debts in hire purchase loan, debt service ratio of less than $60 \%$ and most of them have no alternative source of income. The survey was done on households in three northern states of Malaysia.
\end{abstract}

Index Terms-Debt, debt service ratio, household, Malaysia.

\section{INTRODUCTION}

Over the years, the level of household debt has increased significantly in many countries [1], [2]. Larger amounts of credit borrowed and broader distribution of consumer credit imply that households are facing greater financial stress. This situation creates worries that the excessive leveraging may make the economy and the financial sector vulnerable to instability and crisis, as well as increase the number of bankruptcies among households.

Malaysia was not spared from the household debt problems. The Malaysia's household debt has increased at a rapid rate of 11.1 percent per annum from 2004 to 2009. The household debt to gross domestic products (GDP) recorded high percentage where it increased constantly from 60.4 percent in 2008 to 80.5 percent in 2012; contrary to that, the debt repayment ratio grew at a very slow pace which is from 39.7 percent in 2008 to 43.9 percent in 2012. As at end of March 2013, the Malaysia's household debt to GDP was 82.9 percent and increased sharply to 87.9 percent in 2014 [3], [4] noted that household debt to disposable income ratio of Malaysian as of November, 2010 is 140.4 percent; indicating that on average the loans taken by each household in Malaysia are 1.4 times more than the household incomes. The ratio then increased to 192 percent in late 2012, which is above Singapore, USA, Korea, Thailand and Indonesia. In fact, the ratio has made Malaysia's household debt among the highest in the world. The ratio of Malaysia's household debt to disposable income painted worrisome as it revealed that the households are spending more than they can afford or are using all or most of their income to pay off their debts. High level of indebtedness will place households in a vulnerable position, especially when the economic environment turns

\footnotetext{
Manuscript received March 30, 2016; revised July 14, 2016.

The authors are with Universiti Utara Malaysia, Sintok, Kedah, Malaysia (e-mail: $\quad$ azureen@uum.edu.my, zunarni@uum.edu.my, siew@uum.edu.my).
}

against their favour [5]. However, [1] indicate that a growth in household indebtedness is not a problem per se; but it does become an issue when the debt turns out to be a burden to the borrower which cause them failing to service their debt. Thus, this study tries to observe the indebtedness of Malaysian households by answering three questions; (i) are household indebtedness more likely to be found in certain types of loans?, (ii) do the debts incurred burden the household?, (iii) do the households have other alternative sources of income as their financial back up?

\section{LITERATURE REVIEW}

While there is large empirical evidences on consumer liquidity and credit constraint, very limited formal analysis pertaining to household indebtedness exists. In Malaysia, studies on household debts arise only recently; when economists start questioning about the persistent increased of debts among Malaysian household and discussing its implications. Nonetheless, most of the early studies on Malaysian household debt were limited to identifying the sources of debt financing of the households (i.e., the involvement of financial institutions as financial provider) and the effect of high rising household debts to the GDP [6]-[8]. Although the aggregate statistics provided by the statistics department, such as measures of the households loan payment performance and balance sheet ratios shed some light on the household debt issues, their usefulness is limited. There is no information on how debt is distributed among households that differ economically and demographically [9].

Information on how largely or narrowly household debt is distributed across various income and asset groups assist in assessing their burden of debt. The level of education, age, marital status, and occupation are the critical factors that influence the level of debt among households [1]. Concentration of household debts in certain types of loans is another crucial aspect that need to be focused on; as to provide insight of the short-term and long-term financial commitment of the households. All the information are vital as to provide a comprehensive understanding of household characteristics; the first step to a more in depth discussion on household debt. Whether debt of the households is a burden or not is determined by the capacity of the borrower to service their debts. The increase in debt, which is accompanied by the increase in asset holdings with equal or greater value than the households' debt apparently assist household to meet their debt service payment [9]-[12]. The assets which comprised of fixed assets and liquid assets such as cash acts as a financial backup to the households and may be used to service their debts. Therefore, there are some households who choose to seek for alternative source of income as backup to their main income. 


\section{DATA AND METHODOLOGY}

This study is explanatory in nature where it tried to identify the indebtedness of Malaysian households. In order to achieve the objective of the study, a quantitative research approach was adopted in which primary data were collected using questionnaires. The questionnaire was developed based on measures used in previous related studies to gain information on the indebtedness of households. The population of the study is households located at three northern states of Malaysia, namely, Perlis, Kedah and Penang. For this preliminary study, 45 questionnaires were distributed. The questionnaires were distributed directly to the respondent / households and were collected back on the same day. However, out of 45 questionnaires, only 30 can be analysed due to inadequate information provided by the households. The questionnaire consists of 25 items that measure the characteristics of the households, their capacity to service their debt and their alternative source of income.

In this study, the term debt denotes to loans taken by households, The loans were differentiated into housing loan, hire purchase loan, credit card loan and personal loan; the type of loans that normally associated with household debt [1]. The definition of each type of loans is according to the definition used by the financial institutions. This is an attempt to create consistency between survey-based indicators with the loan definitions given in the financial accounts and to facilitate the households in understanding and answering the questions in the questionnaire. Housing loans are defined as loans earmark for the purchase or construct a house or building; hire purchase loans refer to loans taken to buy private vehicle; credit card loans refer to users who continue to carry a balance on their credit cards after the grace period (the number of days between a customer's credit card statement date and payment due date when interest does not accrue) has expired and the debt begins to bear interest; while personal loans is an unsecured loans taken by household for personal use such as buying a refrigerator, computer, vacation, medical, education, etc.

\section{FINDINGS}

\section{A. Demographic}

Table I shows the demographic profile of the 30 households involved in this preliminary analysis. The households comprised of $16(53 \%)$ female and 14 (47\%) male. Most of the households are Malay, which is $88 \%$, while $13 \%$ of them are Chinese. With regard to age, $57 \%$ of the households are between 31-40 years of age; $27 \%$ households are between $41-50 ; 10 \%$ of them are between 51-60 years of age and only $7 \%$ of them are more than 61 years of age. As for education level, the majority of the households is a degree holder $(40 \%)$, followed by the master holder $(23 \%)$ and $\mathrm{PhD}$ holder $(10 \%)$. There are $3 \%$ households with diploma and $23 \%$ with other qualifications such as primary school, secondary schools or certificates. As marital status is concerned, $70 \%$ of the households are married, $23 \%$ of them are single and $7 \%$ are divorcee. Most of the households have a full time job (83\%), $10 \%$ are unemployed, while another $7 \%$ are self-employed.
TABLE I: DEMOGRAPHIC PROFILE

\begin{tabular}{|c|c|c|}
\hline Variables / $N=30$ & Frequency & Percentage \\
\hline \multicolumn{3}{|l|}{ Gender } \\
\hline Male & 14 & 46.7 \\
\hline Female & 16 & 53.3 \\
\hline \multicolumn{3}{|l|}{ Ethnicity } \\
\hline Malay & 26 & 86.7 \\
\hline Chinese & 4 & 13.3 \\
\hline \multicolumn{3}{|l|}{ Age } \\
\hline $31-40$ & 17 & 56.7 \\
\hline $41-50$ & 8 & 26.7 \\
\hline $51-60$ & 3 & 10.0 \\
\hline$>61$ & 2 & 6.7 \\
\hline \multicolumn{3}{|l|}{ Education Level } \\
\hline Diploma & 1 & 3.3 \\
\hline Degree & 12 & 40.0 \\
\hline Master & 7 & 23.3 \\
\hline $\mathrm{PhD} / \mathrm{DBA}$ & 3 & 10.0 \\
\hline Others & 7 & 23.3 \\
\hline \multicolumn{3}{|l|}{ Marital Status } \\
\hline Single & 7 & 23.3 \\
\hline Married & 21 & 70.0 \\
\hline Divorced & 2 & 6.7 \\
\hline \multicolumn{3}{|l|}{ Occupation } \\
\hline Unemployed & 3 & 10.0 \\
\hline Full time employed & 25 & 83.3 \\
\hline Self employed & 2 & 6.7 \\
\hline \multicolumn{3}{|l|}{ Income } \\
\hline$<$ RM3860 & 16 & 53.3 \\
\hline RM3861-8319 & 13 & 43.3 \\
\hline >RM8320 & 1 & 3.3 \\
\hline
\end{tabular}

\section{B. Types of Loan and Household Debts}

As shown in Table II, all of the households have debts in some type of loan. Most of the households (50\%) have debts in hire-purchase loans; basically to finance their motor vehicle purchases. $43 \%$ of the households have debts in housing loan, while as for credit card loan and personal loan, the same number of households involved in these types of loans, which is $3 \%$.

TABLE II: TYPES OF LOANS AND HOUSEHOLD DEBTS

\begin{tabular}{|c|c|c|}
\hline Types of Loan & Frequency & Percentage \\
\hline Housing Loan & 13 & 43.3 \\
\hline Hire Purchase Loan & 15 & 50.0 \\
\hline Credit card Loan & 1 & 3.3 \\
\hline Personal Loan & 1 & 3.3 \\
\hline
\end{tabular}

\section{Debt Service Ratio of the Households}

The debt service ratio is a key parameter for assessing the capacity of household to service their debt obligations. The debt service ratio in this study is measured based on measurement set by Bank Negara Malaysia, the central bank of Malaysia which is, all outstanding debt repayment obligations from banks and non-banks over income. A household is considered as having the capacity to service their debt obligations if his/her debt service ratio is less than $60 \%$; meaning, the household financial debt is less than $60 \%$ of his/her income. Measuring the debt service ratio of respondents in this study, as shown in Table III, all of the respondents have debt service ratio of less than $60 \%$; implying that the respondents have the capacity to service their debt obligations. It also indicates that although the respondents having debts, but the debts are within their capacity to pay and do not turn out to be a financial burden to them. 
TABLE III: DEBT SERVICE RATIO OF THE HOUSEHOLDS

\begin{tabular}{lll}
\hline Debt Service Ratio & Frequency & Percentage \\
\hline$<60 \%$ & 30 & 100.0 \\
\hline
\end{tabular}

\section{Alternative Source of Income of The Households}

The alternative source of income plays an important role as a financial backup, especially during unexpected events which affects the main stream of income of a household. However, as shown in Table IV, only $23 \%$ of the respondents have an alternative source of income, while another $77 \%$ do not have any alternative sources as their financial backup; implying high dependency of the households on their main stream of income.

TABLE IV: ALTERNATIVE SOURCE OF INCOME

\begin{tabular}{lll}
\hline Other source of Income & Frequency & Percentage \\
\hline Yes & 7 & 23.3 \\
No & 23 & 76.7 \\
\hline
\end{tabular}

Overall, this preliminary study shows that all of the households having debts in some types of loans; with the majority of them involved in hire-purchase loans. However, the debts do not burden them financially, and are still within their financial capacity as evidenced by their debt service ratio. As such, having an alternative source of income might not be a necessity for the households at this point of time.

\section{CONCLUSION}

Although household debts show an increasing trend in Malaysia over the years, the increased should not create panic as long as the households are able to service their debts appropriately. Nonetheless, measures should be taken to educate the households to manage their finances well and reduce their dependency on loans as a method of fulfilling the gap between their income and expenditures. Besides that, a better debt service ratio (i.e., debt service ratio of $40 \%$ ) should also be introduced to create a stronger financial capacity of the households.

\section{REFERENCES}

[1] C. Beer and M. Schurz, "Characteristics of household debt in Austria," Monetary Policy \& The Economy, Q2, pp. 58-79, 2007.

[2] H. J. Kim, D. Lee, J. C. Son, and M. K. Son, " Household indebtedness in Korea: Its causes and sustainability," Japan and The World Economy, vol. 29, pp. 59-76, 2014.

[3] Bank Negara Malaysia, "Annual report," Bank Negara Malaysia Publishing, 2010.

[4] The Edge. (November, 2010). Household debt in Malaysia - Is it sustainable? [Online]. Available: http://www.consumer.org.com

[5] M. Dikko and A. K. Madi, "Casualties and effects of household debt in ASEAN countries," International Journal of Economics, Commerce and Management, vol. III, no. 2, pp. 1-8, 2015.

[6] A. Ng, "Housing and mortgage markets in Malaysia," in Housing and Mortgage Markets in the SEACEN Countries, B Kusmiarso, Ed. SEACEN, 2006, pp. 123-188.

[7] E. Norhana and T. G. Hua, "Household debt in Malaysia," BIS Papers, no. 46, pp. 107-117, 2008.

[8] A. G. Nazreen, "Household Indebtedness and its implications for financial stability in Malaysia," The South East Asian Central Banks Paper, pp. 67-86, 2010.

[9] G. B. Canner, A. B. Kennickell, and C. A. Luckett, "Household sector borrowing and the burden of debt," Federal Reserve Bulletin, pp. 323-338, April 1995.

[10] J. Y. Campbell, "Household finance," The Journal of Finance, vol. LXI, no. 4, pp. 1553-1604, 2006

[11] M. Charpe and P. Flaschel, "Worker debt, default and diversity of financial fragility," IMK Working Paper, pp. 1-43, April 2011.

[12] C. Meniago, J. M. Petersen, M. A. Petersen, and I. P. Mongale, "What causes household debt to increase in South Africa?" Economic Modelling, no. 33, pp. 482-492, 2013.

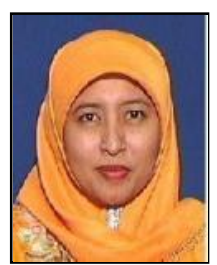

Nora Azureen Abdul Rahman was born in Kuala Lumpur, Malaysia. Her educational background is finance and banking and has obtained her $\mathrm{PhD}$ from Universiti Utara Malaysia, Malaysia in 2012.

She is currently a senior lecturer in the Banking and Risk Management Department of School of Economics, Finance and Banking, College of Business, Universiti Utara Malaysia, Kedah, Malaysia. Her research focus is on banking in the areas of risks, corporate governance, moral hazard, capital regulation and performance. She has been very active in presenting research papers in conferences and has published in national and international proceedings and journals in the areas of banking. She is also actives in writing books and modules, especially in the area of finance, banking and risks.

Dr. Nora Azureen Abdul Rahman is currently an associate member of the Asian Institute of Chartered Bankers (AICB), a professional body for banking and financial services industry in Malaysia. 